\title{
HEAVY METALS IN FLUVIAL SEDIMENTS OF THE ODRA RIVER FLOOD PLAINS - INTRODUCTORY RESEARCH
}

\author{
AleKSANDRA Ibragimow, GraŻYNa GŁosińSKA \\ Adam Mickiewicz University, Collegium Polonicum Słubice, Poland \\ MARCIN SIEPAK \\ Adam Mickiewicz University, Institute of Geology, Department of Hydrogeology and Water Protection, \\ Poznań, Poland \\ BARBARA WALNA \\ Adam Mickiewicz University, Jeziory Ecological Station, Mosina, Poland \\ Manuscript received January 4, 2010 \\ Revised version February 15, 2010
}

Ibragimow A., GłosińsKa G., SiepaK M. \& Walna B., 2010. Heavy metals in fluvial sediments of the Odra River flood plains - introductory research. Questiones Geographiceae 29(1), Adam Mickiewicz University Press, Poznań 2010, pp. 37-47, Figs 6. Tabs 2. ISBN 978-83-232-2136-4. ISSN 0137-477X. DOI: 10.2478/v10117-010-0004-7.

ABSTRACT. The article presents the results of research on concentrations of heavy metals $(\mathrm{Cd}, \mathrm{Cr}, \mathrm{Cu}, \mathrm{Ni}, \mathrm{Pb}$ and $\mathrm{Zn}$ ) in fluvial sediment samples collected in the flood plains of the Odra River. The samples were collected from the presently flooded area and from the area which was formerly flooded. The extraction of sediment samples was conducted using aqua regia and four other extractants: $0.01 \mathrm{M} \mathrm{CaCl}, 0.1 \mathrm{M} \mathrm{HCl}, 0.005 \mathrm{M} \mathrm{DTPA}$ and $0.02 \mathrm{M}$ EDTA. The analysis of the results revealed different concentration values for particular sample collection sites situated along the course of the Odra River. The differentiation of metal concentrations in the investigated samples depending on the extractants was also observed. The concentrations of metals were determined using the technique of atomic absorption spectrometry with flame atomization (F-AAS).

KEYWORDs: heavy metals, single extraction, fluvial sediments, the Odra River

Aleksandra Ibragimow, Grażyna Głosińska, Adam Mickiewicz University, Collegium Polonicum Stubice, Kościuszki 1, 69-100 Stubice, Poland

Marcin Siepak, Adam Mickiewicz University, Institute of Geology, Department of Hydrogeology and Water Protection, Maków Polnych 16, 61-606 Poznań, Poland, e-mail: marcin.siepak@amu.edu.pl

Barbara Walna, Adam Mickiewicz University, Jeziory Ecological Station, PO Box 40, 62-050 Mosina, Poland, e-mail: walna@amu.edu.pl 


\section{Introduction}

Heavy metals are one of the most important factors which threaten living organisms because, once introduced to the natural environment, they undergo biological accumulation. This concerns especially $\mathrm{Cd}, \mathrm{Cu}, \mathrm{Pb}$ and $\mathrm{Zn}$ (Kabata-Pendias \& Pendias, 1999). The degree of threat is not determined by the total concentrations of metals but by the forms of metals which may be potentially absorbed by living organisms (Quevauviller, 2002).

Various kinds of pollutants are introduced into the Odra River. This results from dense population and industrialisation of the catchment areas in its upper course. The study of fluvial accumulation of sediments and heavy metals bound with them resulted in emphasizing the significance of flood plains as the place where pollution accumulates (Walling et al., 2003; Owens et al., 1999). The deposited pollutants cause major reduction of the load transported by the river to its mouth (Leece \& Pavlowsky, 1997; Miller, 1997; Taylor, 1996; Zhao et al., 1999; Hudson-Edwards et al., 1999). The estimated pollution load for the Odra River amounts to $40-50 \%$ (Lewandowski \& Przewłocki, 1995).

The mobility of heavy metals compounds depends on their solubility, which is affected by many factors, such as $\mathrm{pH}$, cation exchange capacity of the solid phase, redox potential, grain size composition and moisture. In polluted soils, heavy metals may occur as mobile forms - they are subject to sorption, complexation and coprecipitation with soil particles and, in favourable physico-chemical conditions, they increase the amount of potentially available metals (Lopez-Sanchez et al., 2002; Quevauviller, 2002).

Extraction procedures - single extraction and sequential extraction - are used to determine available forms of heavy metals in sediments and soil. The methods of sequential extraction are based on gradual release of metals occurring in different speciation forms by means of extraction using specific extractants (Tessier et al., 1979; Hulanicki, 1998).

The methods of single extraction involve subjecting a soil sample to one extractant in order to determine forms of metals soluble in extractant solutions selected to reflect the bioavailability of a given metal for plants or organisms (available forms) and susceptibility of metals to leaching (mainly in highly polluted soil and waste) (Karczewska, 2002). The single extraction is a simple and fast method which provides information concerning a potential environmental hazard. It involves the use of so called 'soft extractants', which include non-buffered salt solutions (e.g. $\mathrm{KCl}, \mathrm{CaCl}_{2}, \mathrm{NaNO}_{3}$ ), acid of different concentrations (e.g. $0.1 \mathrm{M}$ or $1 \mathrm{M} \mathrm{HCl}$ ) and solutions of complexant agents (e.g. EDTA, DTPA) (Quevauviller, 2002). In comparison with the sequential extraction, the procedures of single extraction reduce the possibility of mistake at particular stages of extraction (Pijnenburg et al., 2007). Non-buffered salt solutions first and foremost release the cation - exchangeable fraction; diluted acids extract heavy metals of the exchangeable element and carbonate fraction, bound with $\mathrm{Fe}$ and Mn oxides and organic matter; complexing agents extract the metals of the exchangeable element fraction and organic matter (Karczewska, 2002).

The study aimed at (1) conducting introductory research on the level of total concentrations of heavy metals $(\mathrm{Cd}, \mathrm{Cr}, \mathrm{Cu}, \mathrm{Ni}, \mathrm{Pb}$ and $\mathrm{Zn})$ in fluvial sediments of flood plains of the mid Odra Valley, deposited in the present and former flood area, as well as at (2) determining the easily available forms and (3) defining the extracting effectiveness of the used reagents with reference to the investigated metals. The research is planned to be continued for a bigger number of samples in several cross-sections.

\section{Materials and methods}

The sediment samples were collected in April 2009 , in the River Odra Valley, at the section from the $564^{\text {th }}$ to $574^{\text {th }} \mathrm{km}$ of the river course. They were collected from three cross-sections: Rybocice 1 R1, Rybocice 2 - R2 and Kunice - K (Fig. 1). In each section, two sediment samples were collected in the distance of about $10 \mathrm{~m}$ from the flood bank: from the present flood area (A) and from the former flood area (B). The investigated section of the river belongs to the Nature 2000 Mid-Oder Valley PLB080004 area.

The sediment samples of the Odra flood plains were collected from the surface layer (up 


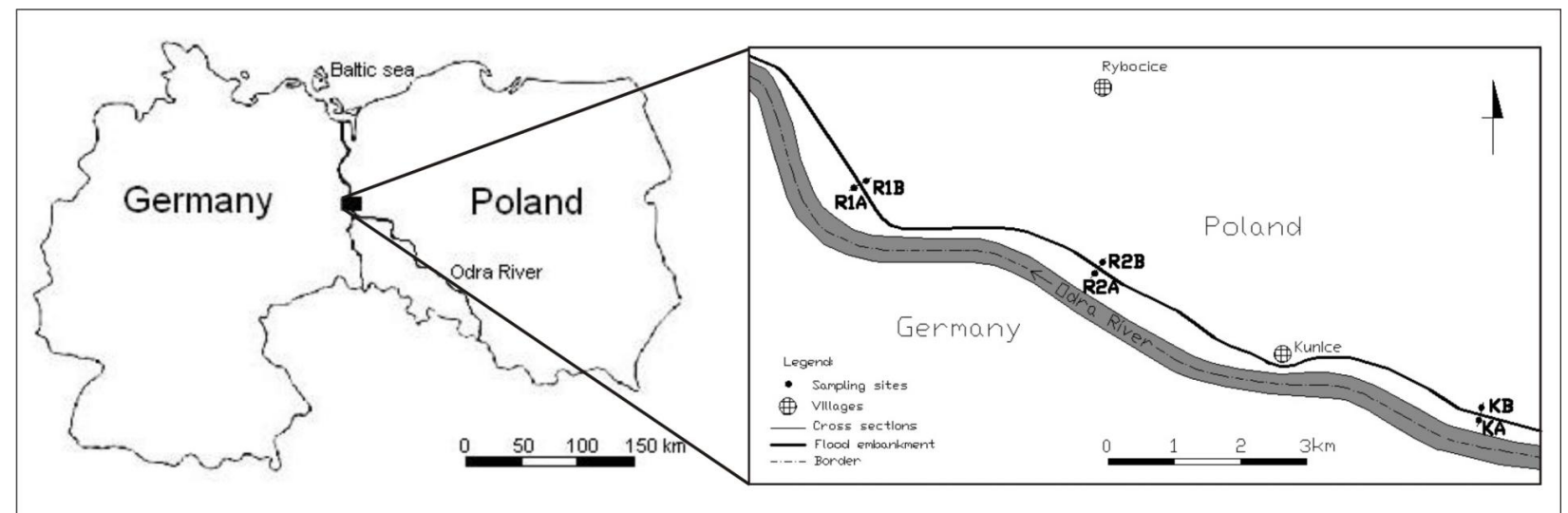

Fig. 1. Study area. R1A, R1B, R2A, R2B, KA, KB - sampling sites

to $20 \mathrm{~cm}$ ) into polyethylene bags. The samples were dried in the room temperature and sieved with mesh sizes of $2.0 \mathrm{~mm}$.

The samples were then subjected to mineralization with aqua regia according to the Polish Norm (PN-ISO 11466). The single extraction was performed using the following reagents and extraction conditions (Quavaviller, 2002; Karczewska \& Kabała, 2008): 0.01M $\mathrm{CaCl}_{2}$ (1:10 soil/ solution, shaking in an end-over shaker for $2 \mathrm{~h}$ ); $0.1 \mathrm{M} \mathrm{HCl}$ (1:10 soil/solution, shaking in an end- over shaker for 1h); 0.02M EDTA (1:5 soil/solution, shaking in an end-over shaker for $0.5 \mathrm{~h}$ ); $0.005 \mathrm{M}$ DTPA (1:2 soil/solution, shaking in an end-over shaker for $2 \mathrm{~h}$ ).

Determinations of the total content and available forms of heavy metals were conducted using the technique of atomic absorption spectrometry with acetylene-air flame atomization (F-AAS). The fast sequential atomic absorption spectrometer SpectrAA 280 FS manufactured by Varian (Australia) was used in the determinations. The

Table 1. Conditions and parameters of the analytical technique (F-AAS) used for determinations of Cd, Cr, Cu, $\mathrm{Pb}, \mathrm{Zn}$ AND Ni.

\begin{tabular}{|l|l|c|c|c|c|c|c|}
\hline \multicolumn{1}{|c|}{ Parameter } & & $\mathbf{C d}$ & $\mathbf{C r}$ & $\mathbf{C u}$ & $\mathbf{P b}$ & $\mathbf{Z n}$ & $\mathbf{N i}$ \\
\hline Wavelength & {$[\mathrm{nm}]$} & 228.8 & 357.9 & 213.9 & 217.0 & 213.9 & 232.0 \\
\hline Slit width & {$[\mathrm{nm}]$} & 0.5 & 0.2 & 1.0 & 1.0 & 1.0 & 0.2 \\
\hline Lamp current & {$[\mathrm{mA}]$} & 4.0 & 7.0 & 4.0 & 10.0 & 5.0 & 4.0 \\
\hline Oxid flow & {$\left[\mathrm{L} \mathrm{min}^{-1}\right]$} & 12.7 & 11.5 & 12.7 & 12.7 & 12.7 & 12.7 \\
\hline Fuel flow & {$\left[\mathrm{L} \mathrm{min}^{-1}\right]$} & 2.5 & 3.1 & 2.5 & 2.5 & 2.5 & 2.5 \\
\hline Sample flow rate & {$\left[\mathrm{mL} \mathrm{min}^{-1}\right]$} & 5.0 & 5.0 & 5.0 & 5.0 & 5.0 & 5.0 \\
\hline Flame type & \multicolumn{2}{|c|}{ Air/Acetylene } & & & \\
\hline Detection limit & {$\left[3 \sigma ; \mathrm{mg} \mathrm{kg}^{-1}\right]$} & 0.01 & 0.02 & 0.01 & 0.03 & 0.02 & 0.03 \\
\hline Determination limit & {$\left[6 \sigma ; \mathrm{mg} \mathrm{kg}^{-1}\right]$} & 0.03 & 0.06 & 0.03 & 0.09 & 0.06 & 0.09 \\
\hline
\end{tabular}


samples were batched using the autosampler SPS3 manufactured by Varian (Australia). The instrumental parameters and the parameters of analytical method have been presented in Table 1.

The reagents used in determinations were analytically pure and water was deionised to a resistivity of $18.2 \mathrm{M} \Omega \cdot \mathrm{cm}$ in a Direct-Q ${ }^{\circledR} 3$ Ultrapure Water System apparatus (Millipore, France). Standard solutions were made using Merck commercial standards for AAS (Merck, Darmstadt, Germany).

The accuracy of measurements was determined based on the coefficient of variation $(\mathrm{CV})$, with the assumed acceptance criterion of $15 \%$. Its value was the lowest for $0.1 \mathrm{M} \mathrm{HCl}$ extraction
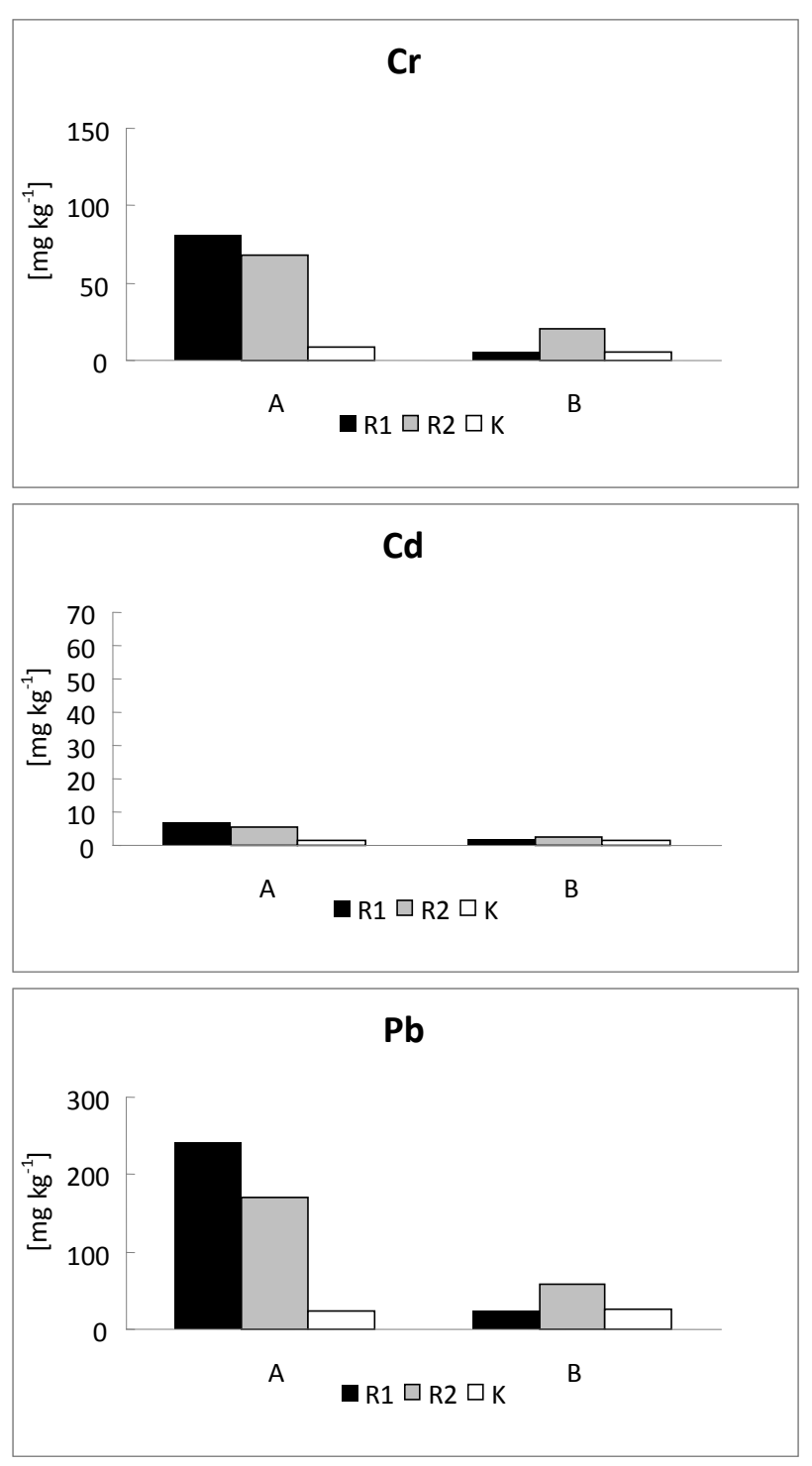

Fig. 2. Totat concentrations of heavy metals in fluvial sediment samples.

A - presently flooded area, B - formerly flooded area; Cross-sections: R1 - Rybocice 1, R2 - Rybocice2, K - Kunice (from 3 to 12\%). Higher values of CV were obtained for the extraction with complexing agents (from 2 to $17 \%$ ).

\section{Results and discussion}

\section{Total concentration of heavy metals in fluvial sediment samples}

The research on the total content of heavy metals aimed at defining the level of pollution of fluvial sediment samples with heavy metals and evaluating the degree of metal extraction using specific extractants. The concentrations of
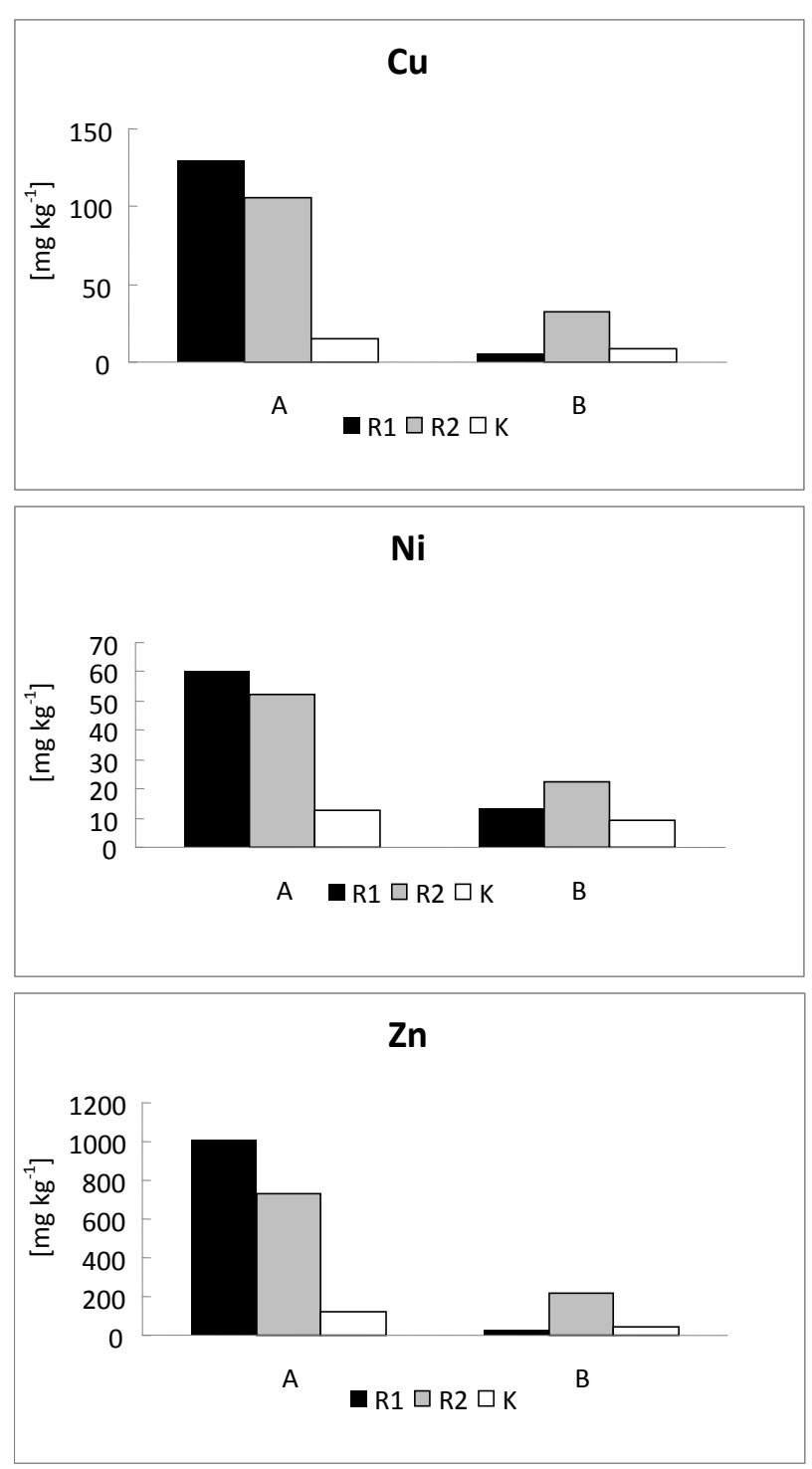
the determined metals amounted $\left(\mathrm{mg} \mathrm{kg}^{-1}\right): 1.4$ 7 cadmium, 9.2 - 60 nickel; 5.4 - 81 chromium; 5.7 - 129 copper; 24.5 - 242 lead; 23.6 - 1006 zinc (Fig. 2). With the exception of zinc, these values exceeded the concentrations of metals determined in the previous years (Bojakowska \& Sokołowska, 1998), which amounted to $\left(\mathrm{mg} \mathrm{kg}^{-1}\right)$ : $<0.5$ - 6.6 cadmium, 3 - 42 nickel, 5 - 276 copper, 3 - 681 lead, and 39 - 1663 zinc.

Alarmingly high concentrations of cadmium were determined in the investigated area, with the obtained values comparable to the level of pollution observed in the fluvial sediment samples in the River Kilmastulla (Ireland), within the area of impact of former coal mines (Aslibekian $\&$ Moles, 2003), as well as in the valleys of the rivers Scheldt and Leie (Vandecasteele et al., 2004). The observed concentrations of lead in the investigated samples are lower than the concentrations of lead in the sediments samples collected in the valleys of the rivers Scheldt and Leie in Belgium (Vandecasteele et al., 2004). Much lower concentrations of zinc and copper occur in the agricultural and fertilized soils of the lower Vistula Valley (Dąbkowska-Naskręt et al., 2000), while similar values of concentrations of these metals were determined in the sediments samples collected in the valleys of rivers Scheldt and Leie (Vandecasteele et al., 2004).

The issue of polluting the alluvium of the River Oder with heavy metals has been addressed by many researchers (Adamiec \& Helios-Rybicka, 2002; Boszke et al., 2004; Helios- Rybicka et al., 2005; Głosińska et al., 2005). However, the direct comparison of the studies is difficult as they discussed the concentrations in fractions of either different particle size distribution or obtained by means of different extraction methods.

The presented results of determination of total heavy metals concentrations were compared with the allowable concentrations defined in the Minister of the Environment Directive (2002) in mg kg-1: 1 - cadmium, 35 - nickel, 30 - copper, 50 lead, 100 - zinc and 50 - chromium. The comparison revealed that the total concentrations exceed the values of allowable concentrations for zinc, lead, copper, chromium, nickel and cadmium. It was also observed that the total concentrations of determined metals in the present flood area were higher than the concentrations in the former flood area (Fig. 2).

\section{Available forms of heavy metals in fluvial sediment samples}

Based on the comparison of the obtained results, it may be stated that the concentrations of extracted metals differ from one another depending on the extractant used, location of the sampling site at the flood bank, as well as on the location of the sampling site along the course of the Oder River.

The concentrations of the investigated metals extracted using $0.01 \mathrm{M} \mathrm{CaCl}$ amounted to $\left(\mathrm{mg} \mathrm{kg}^{-1}\right): 0.53$ - 5.61 zinc; 0.39 - 0.91 lead; 0.22 - 0.57 copper; <0.02 - 0.23 chromium; <0.03 - 0.13 nickel; 0.04 - 0.13 cadmium (Fig. 3). The obtained concentrations were compared with the total content and the percentage content of the extracted metals was calculated. The values obtained for $0.01 \mathrm{M} \mathrm{CaCl}_{2}$ were as follows: $0.2-2.3 \%$ zinc, 0.2 - $3.5 \%$ lead, $0.4-7.4 \%$ copper, BLD - $1.1 \%$ chromium, BLD - 0.9\% nickel; 1.7 - 8.6\% cadmium (Table 2). The extractant proved least effective in the case of nickel and most effective in the case of cadmium.

As a result of $0.1 \mathrm{M} \mathrm{HCl}$ extraction, higher concentrations of the investigated metals were determined in comparison with $0.01 \mathrm{M} \mathrm{CaCl}_{2}$ extraction. The concentrations were as follows $\left(\mathrm{mg} \mathrm{kg}^{-1}\right): 3.30$ - 529 zinc; 3.29 - 33.9 lead; 1.21 65.6 copper; 0.24 - 4.92 chromium; 1.97 - 16.7 nickel and 0.33 - 4.98 cadmium (Fig. 4). The use of hydrochloric acid enabled to extract: $1.5-72 \%$ zinc, $8.0-33.6 \%$ lead, 3.6 - $61.9 \%$ copper, $1.7-11 \%$ chromium, $11.7-33.6 \%$ nickel; $18.7-88.6 \%$ of cadmium (Table 2). The extractant proved least effective in the case of chromium and most effective in the case of cadmium.

The concentrations of the investigated heavy metals determined after $0.005 \mathrm{M}$ DTPA extractions were as follows $\left(\mathrm{mg} \mathrm{kg}^{-1}\right): 0.54-227$ zinc; 0.63 - 18.9 lead; $0.40-53.7$ copper; $0.23-4.93$ nickel and $0.08-2.24$ cadmium. In the case of $0.005 \mathrm{M}$ DTPA extraction, chromium was not determined (the concentration below the limit of analytical technique determination) (Fig. 5), whereas the concentrations of the remaining metals were lower 

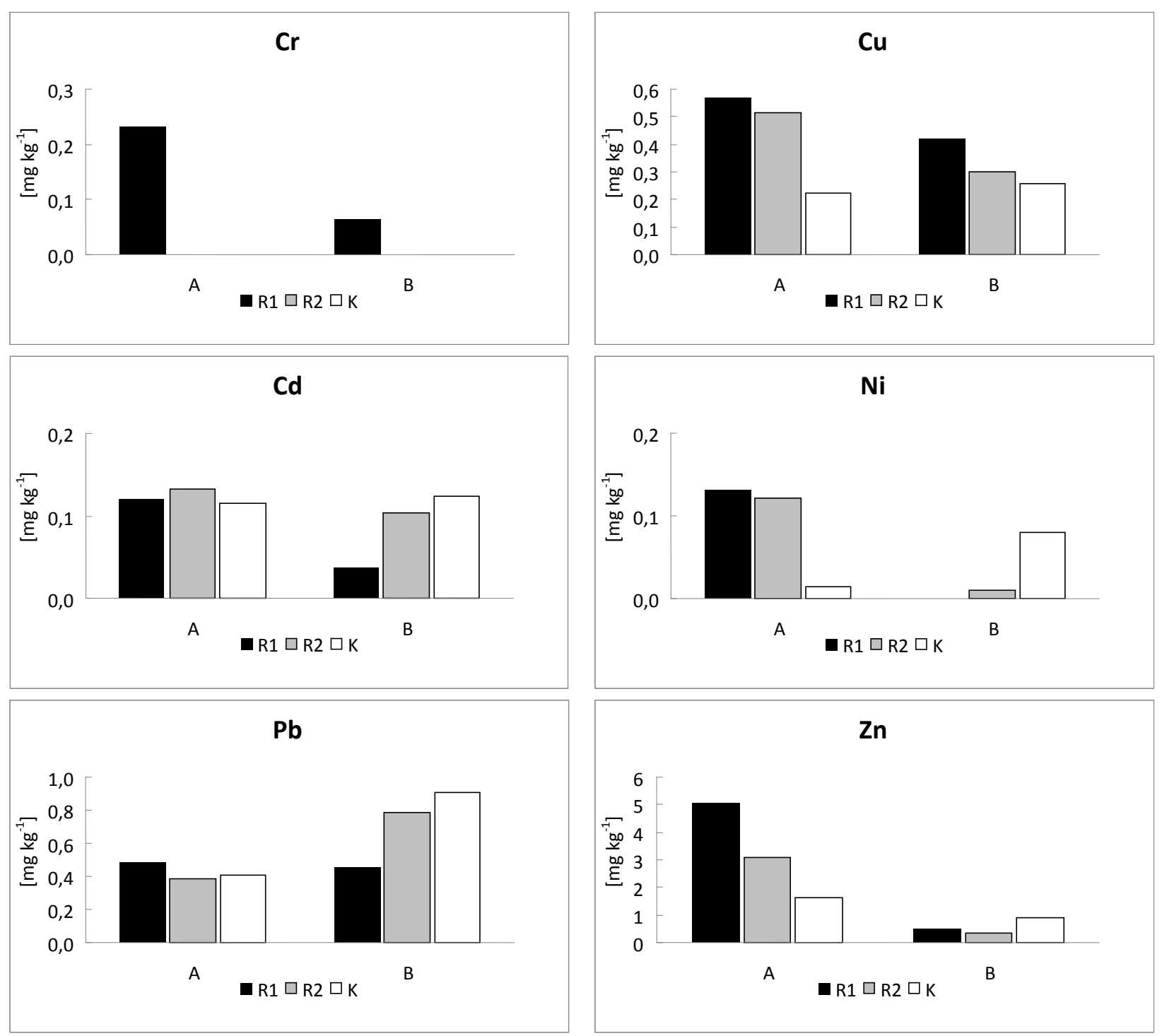

Fig. 3. Concentrations of $\mathrm{CaCl}_{2}$ - extractable metals.

A - presently flooded area, B - formerly flooded area; Cross-sections: R1 - Rybocice 1, R2 - Rybocice2, K - Kunice

in comparison with $0.1 \mathrm{M} \mathrm{HCl}$ extraction. The concentrations of the investigated heavy metals determined after 0.02M EDTA extractions were as follows $\left(\mathrm{mg} \mathrm{kg}^{-1}\right)$ : 1.43 - 378 zinc; 3.39 - 92.0 lead; 1.29 - 81.6 copper; $1.36-16.2$ nickel and 0.30 - 3.66 cadmium. The use of two complexing extractants enabled to draw the conclusion that the concentrations determined as a result of $0.02 \mathrm{M}$ EDTA extraction (Fig. 6) were at a similar level as or higher than those obtained in $0.005 \mathrm{M}$ DTPA extraction (Table 2).

The percentage amount of the released metal in comparison with the total value indicated that 0.02M EDTA released larger quantities of metals compared to 0.005M DTPA. Complexing solutions proved least effective in the case of chromium and most effective in the case of copper (0.005M DTPA - Fig. 5) and cadmium (0.02M EDTA - Fig. 6). The effectiveness of extraction of cadmium from the samples of soils limited by the flood bank in the Rybocice 2 cross-section (66\%) using 0.02M EDTA solution was comparable with the results of a similar test for the soils of the polluted valley of the River Kilmastulla (Irleland); (Aslibekian \& Moles, 2003). In the samples of sediments collected in the present flood area (R1A, R2A - Fig. 1), according to the soil classification based on EDTA extraction results (Aslibekian \& Moles, 2003), the threshold values for some metals ( $0.8 \mathrm{mg} \mathrm{kg}^{-1}$ cadmium, 25 $\mathrm{mg} \mathrm{kg}^{-1}$ lead, $20 \mathrm{mg} \mathrm{kg}^{-1}$ zinc) were exceeded: cad- 

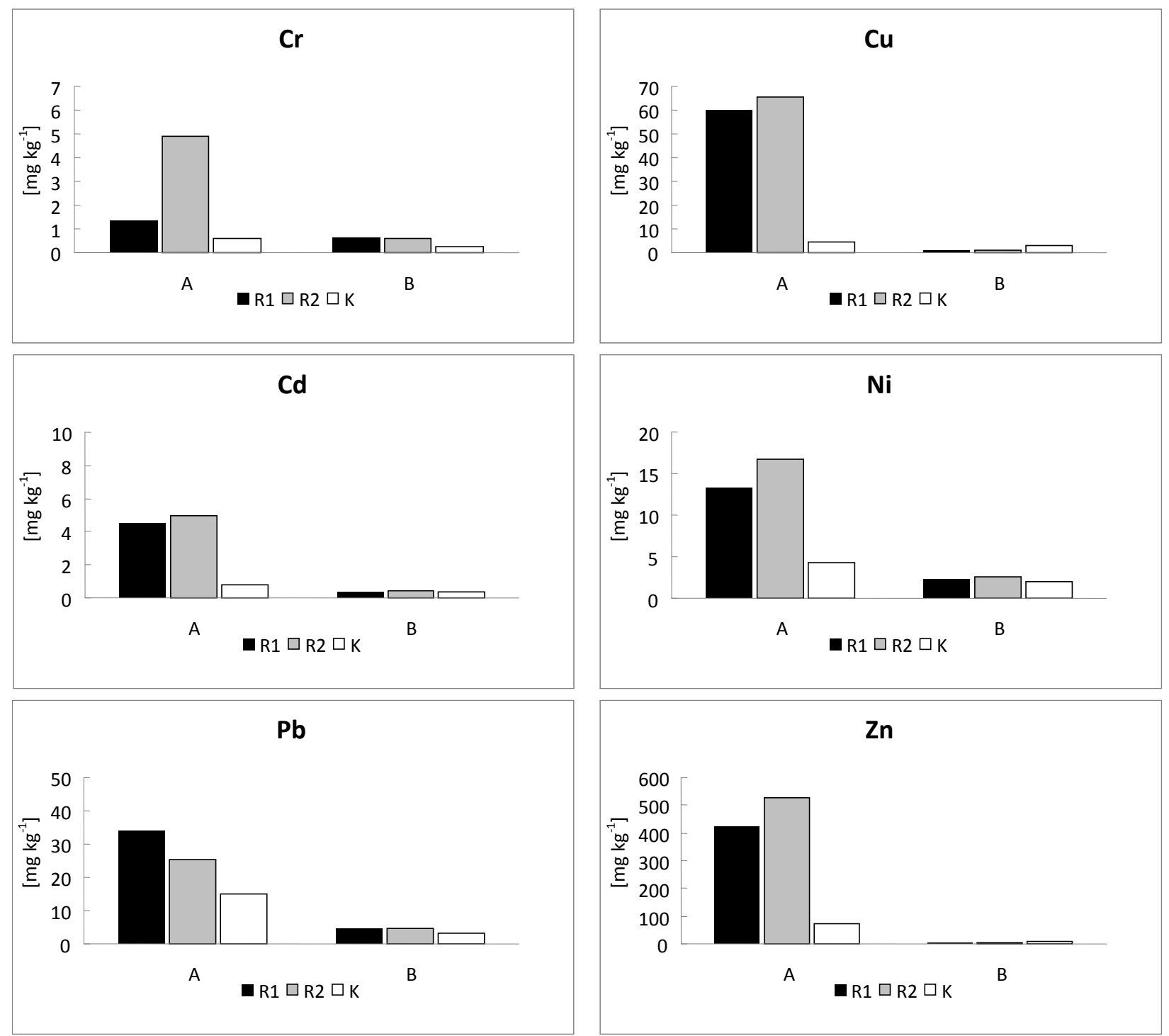

Fig. 4. Concentrations of $\mathrm{HCl}$ - extractable metals.

A - presently flooded area, B - formerly flooded area; Cross-sections: R1 - Rybocice 1, R2 - Rybocice2, K - Kunice

mium over four times, lead four times, zinc sixteen times.

Irrespective of the extractant used, chromium was extracted in minimal quantities, which is related to very low availability of this metal, in spite of its quite high total content. The low level of chromium extraction is also confirmed by the studies into the sediments of flood plains of the rivers Rhein and Meza in Holland (Schroeder et al., 2005).

As a result of $0.005 \mathrm{M} \mathrm{DTPA}, 0.02 \mathrm{M}$ EDTA and $0.1 \mathrm{M} \mathrm{HCl}$ extractions, significant differences in concentrations of zinc, lead and copper obtained in the presently and formerly flooded areas were observed. Higher concentrations in the present flood area, in comparison with the concentra- tions in the former flood area (extraction DTPA, EDTA and $\mathrm{HCl}$ ), may be linked to the chemical form of the metal. Similar differences in pollution by metals in the areas more and less frequently flooded were also observed in the mid-Vistula Valley (Gąsior \& Paśko, 2007) and in the valleys of the following rivers: Amer, Rhein, Dommel (Bleeker \& Van Gestel, 2007; Schipper et al., 2008; Van Gestel, 2008).

The forms of metals released during $0.01 \mathrm{M}$ $\mathrm{CaCl}_{2}$ extraction correspond with slight changes in environmental conditions, and the capacity for $0.01 \mathrm{M} \mathrm{CaCl}_{2}$ extraction is the measure of present availability of metals. The forms which are stronger bound, potentially available, activated in the 


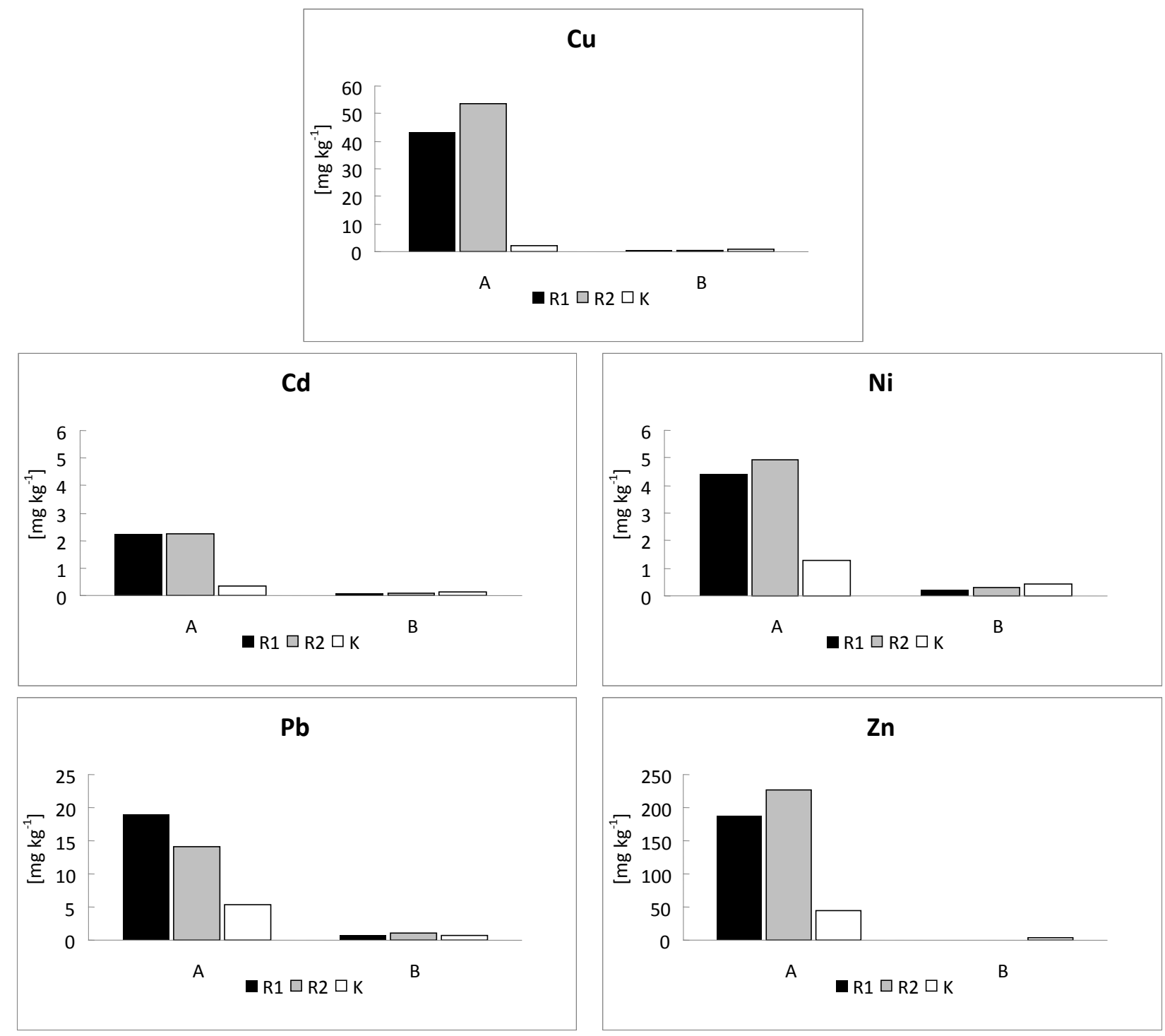

Fig. 5. Concentrations of DTPA - extractable metals.

A - presently flooded area, B - formerly flooded area; Cross-sections: R1 - Rybocice 1, R2 - Rybocice2, K - Kunice

case of visible changes of environmental parameters, such as $\mathrm{pH}$ reaction or redox potential, correspond with the concentrations of metals obtained in the extractions with $0.1 \mathrm{M} \mathrm{HCl}$ and complexing agents. The alarming fact is that, from among the investigated metals, the most available is cadmium (extracted with $0.01 \mathrm{M} \mathrm{CaCl}$ ), its extraction with reference to the percentage content is from 1.7 to $8.6 \%$. High availability of cadmium is also confirmed in other studies (Bleeker \& Van Gestel, 2007).

Despite the introductory nature of the conducted research and small amount of the analysed samples, the influence of the width of the valley on the concentration values of metals deposited in the sediments (higher concentrations of the determined metals recorded at sites R1A and R2A) may be observed for the results of available metal forms and for total concentrations. The comparison of the total content in samples collected in the present and former flood area reveals the role of the river as the agent carrying significant amounts of heavy metals.

\section{Conclusions}

- Introductory research on pollution of sediments of the mid-Oder flood plains with heavy metals, aiming at the determination of available 


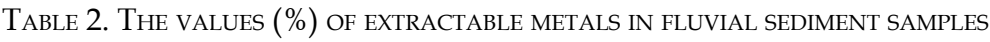

\begin{tabular}{|c|c|c|c|c|c|}
\hline \multirow{3}{*}{ Metals } & \multirow{3}{*}{ Samples } & \multicolumn{4}{|c|}{ Extracting solution } \\
\hline & & $0.01 \mathrm{M} \mathrm{CaCl}_{2}$ & $0.1 \mathrm{M} \mathrm{HCl}$ & 0.005M DTPA & 0.02M EDTA \\
\hline & & \multicolumn{4}{|c|}{ [\%] } \\
\hline \multirow{6}{*}{$\mathrm{Zn}$} & R1A & 0.5 & 42.2 & 18.7 & 29.8 \\
\hline & R1B & 2.2 & 16.0 & 2.9 & 6.8 \\
\hline & R2A & 0.4 & 72.0 & 30.9 & 51.4 \\
\hline & $\mathrm{R} 2 \mathrm{~B}$ & 2.6 & 1.5 & 0.3 & 0.7 \\
\hline & KA & 1.4 & 59.9 & 37.0 & 49.5 \\
\hline & KB & 2.3 & 24.5 & 7.3 & 16.1 \\
\hline \multirow{6}{*}{$\mathrm{Pb}$} & R1A & 0.2 & 14.0 & 7.8 & 38.0 \\
\hline & R1B & 1.9 & 18.6 & 2.5 & 13.9 \\
\hline & $\mathrm{R} 2 \mathrm{~A}$ & 0.2 & 15.0 & 8.3 & 49.6 \\
\hline & $\mathrm{R} 2 \mathrm{~B}$ & 1.3 & 8.0 & 1.8 & 6.8 \\
\hline & KA & 0.9 & 33.6 & 12.1 & 42.0 \\
\hline & KB & 3.5 & 12.7 & 3.0 & 13.5 \\
\hline \multirow{6}{*}{$\mathrm{Cu}$} & R1A & 0.4 & 46.4 & 33.6 & 55.4 \\
\hline & R1B & 7.4 & 21.2 & 7.0 & 22.6 \\
\hline & R2A & 0.5 & 61.9 & 50.7 & 77.0 \\
\hline & $\mathrm{R} 2 \mathrm{~B}$ & 0.9 & 3.5 & 2.0 & 4.5 \\
\hline & KA & 1.5 & 28.9 & 15.2 & 37.6 \\
\hline & KB & 2.9 & 35.0 & 12.2 & 32.4 \\
\hline \multirow{6}{*}{$\mathrm{Cr}$} & R1A & 0.3 & 1.7 & BLD & 1.0 \\
\hline & R1B & 1.1 & 11.0 & BLD & 7.9 \\
\hline & $\mathrm{R} 2 \mathrm{~A}$ & BLD & 7.2 & BLD & 1.3 \\
\hline & R2B & BLD & 3.0 & BLD & 3.2 \\
\hline & KA & BLD & 6.8 & BLD & 3.3 \\
\hline & $\mathrm{KB}$ & BLD & 4.5 & BLD & 1.9 \\
\hline \multirow{6}{*}{$\mathrm{Ni}$} & R1A & 0.2 & 22.2 & 7.4 & 21.0 \\
\hline & R1B & BLD & 18.2 & 1.8 & 10.6 \\
\hline & $\mathrm{R} 2 \mathrm{~A}$ & 0.2 & 32.0 & 9.5 & 31.0 \\
\hline & $\mathrm{R} 2 \mathrm{~B}$ & 0.1 & 11.7 & 1.4 & 7.4 \\
\hline & KA & 0.1 & 33.6 & 10.1 & 28.1 \\
\hline & $\mathrm{KB}$ & 0.9 & 21.5 & 4.8 & 16.8 \\
\hline \multirow{6}{*}{$\mathrm{Cd}$} & R1A & 1.7 & 64.7 & 31.7 & 52.1 \\
\hline & R1B & 2.0 & 18.7 & 4.4 & 16.7 \\
\hline & $\mathrm{R} 2 \mathrm{~A}$ & 2.4 & 88.6 & 39.9 & 65.1 \\
\hline & R2B & 4.4 & 19.3 & 4.2 & 14.4 \\
\hline & KA & 6.8 & 47.0 & 20.0 & 38.6 \\
\hline & $\mathrm{KB}$ & 8.6 & 22.8 & 7.6 & 20.7 \\
\hline
\end{tabular}

BLD; below limit of detection 


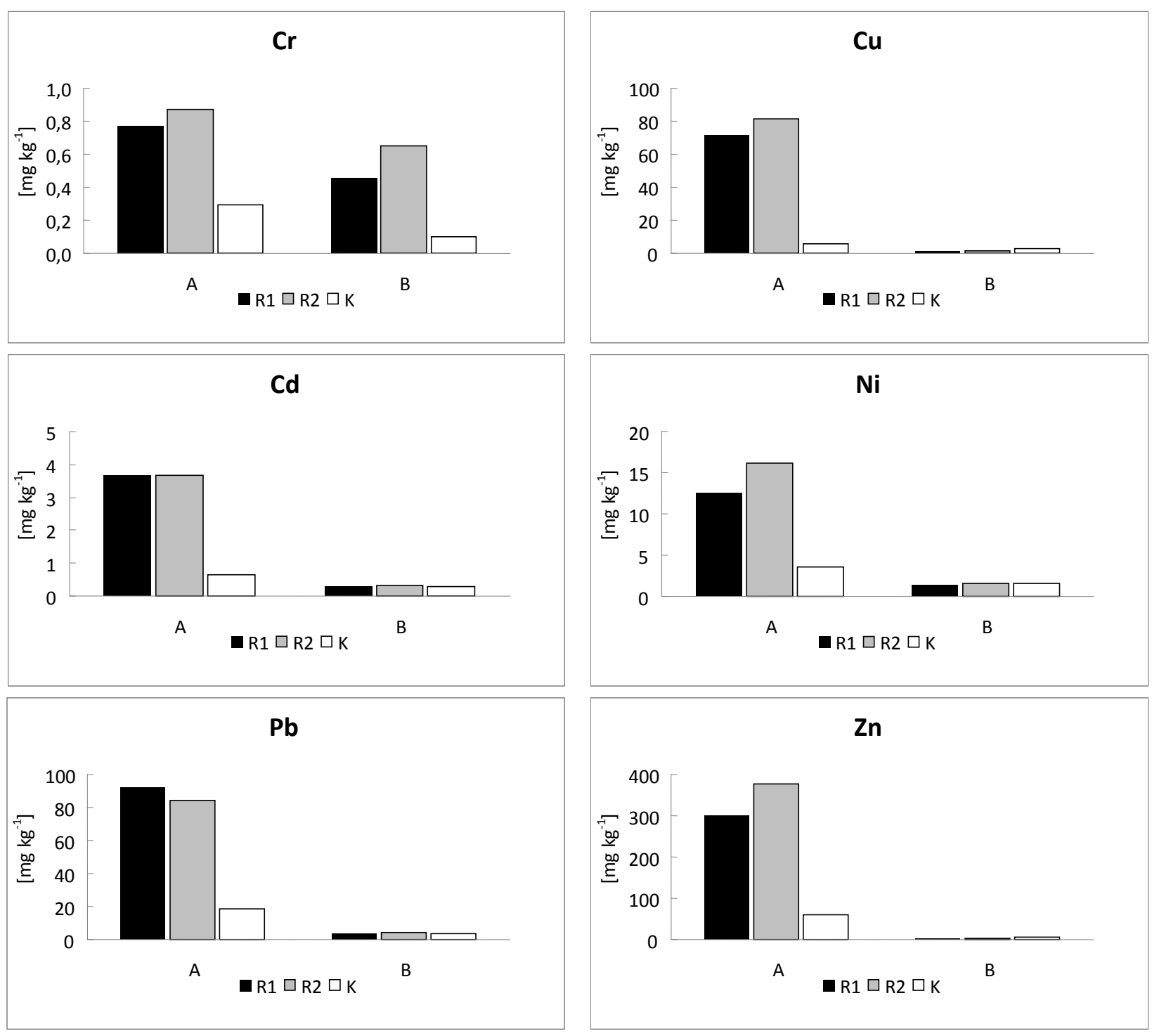

Fig. 6. Concentrations of EDTA extractable metals.

A - presently flooded area, B - formerly flooded area; Cross-sections: R1 - Rybocice 1, R2 - Rybocice2, K - Kunice

forms concentrations, revealed high concentrations of cadmium, copper, lead and zinc.

- In the case of $\mathrm{Cu}$ and $\mathrm{Pb}$ extraction, the sequence of the most effective extractant was $0.02 \mathrm{M}$ EDTA $>0.1 \mathrm{M} \mathrm{HCl}>0.005 \mathrm{M}$ DTPA $>0.01 \mathrm{M} \mathrm{CaCl}_{2}$ while in the case of $\mathrm{Cd}, \mathrm{Zn}, \mathrm{Ni}$ and $\mathrm{Cr}$, it was $0.1 \mathrm{M}$ $\mathrm{HCl}>0.02 \mathrm{M}$ EDTA $>0.005 \mathrm{M}$ DTPA $>0.1 \mathrm{M} \mathrm{CaCl}_{2}$.

- The comparison of the total content in samples collected in the present and former flood areas reveals the role of the river as the agent carrying significant amounts of heavy metals, as well as the influence of retention time of sediments, which affects the processes shaping the form and availability of heavy metals.

\section{References}

Adamiec E. \& Helios-Rybicka E., 2002. Distribution of pollutants in the Odra River system. Assessment of total and mobile heavy metals content in the suspended matter and sediments of the Odra River system and recommendations for river chemical monitoring. Polish Journal of Environmental Studies 11: 675-688.

AslibeKian O. \& Moles R., 2003. Environmental risk assessment of metals contaminated soils at Silvermines abandoned mine site, CoTipperary, Ireland. Environmental Geochemistry and Health 25: 247-266. DOI: 10.1023/A: 1023251102402

BleEKER E.A.J. \& VAN GeSTEL C.A.M., 2007. Effects of spatial and temporal variation in metal availability on earth- 
worms in floodplain soils of the river Dommel, The Netherlands. Environmental Pollution 148: 824-832. DOI: 10.1016/j.envpol.2007.01.034

BојАKоWSKA I. \& SокоŁоWSKA G., 1998. Geochemical purity classes of bottom sediments (in Polish). Przeglad Geologiczny 46: 49-55.

BoszKe L., Sobczyński T., GŁosińsKa G., Kowalski A. \& SiEPAK J., 2004. Distribution of mercury and other heavy metals in bottom sediments of the Middle Odra River (Germany/Poland). Polish Journal of Environmental Studies 13: 595-502.

DĄikKOWSKA-NASKRĘT H., Kobierski M. \& RÓŻAŃSKi S., 2000. Trace metals distribution and mobility in alluwial soils of the Wisła River Valley, Poland. Mengen Spurenelement. 20, 152-157.

GĄSIOR J. \& PAŚKO J., 2007. Effect of floods on the contents of soluble element forms against a background of soil differentiation (in Polish). Zesz. Problem. Post. Nauk Roln. 520: 39-46.

GŁosińska G., Sobczyński T., Boszke L., BierŁa K. \& SiepaK J., 2005. Fractionation of some heavy metals in bottom sediments from the middle Odra River. Polish Journal of Environmental Studies 14: 305-317.

Helios-Rybicka E.T., SiKora W., Wójcik R., Wardas M., StrZebońsKa M., AdAMiec E. \& Łagaj Ł., 2000. Estimation of pollution by heavy metals of bottom sediments in the Upper and Middle Odra river (in Polish). Gospodarka Wodna 8: 300-304.

Hudson-Edwards K.A., Shell C. \& Macklin M.G., 1999. Mineralogy and geochemistry of alluvium contaminated by metal mining in the Rio Tinto area, southwest Spain. Applied Geochemistry 14: 1015-1030. DOI: 10.1016/ S0883-2927(99)00008-6

HulANICKI A., 1998. Speciation and speciation analysis (in Polish). In: A. Kabata-Pendias \& B. Szteke (eds.), Quality problems in trace analysis in environmental studies. Wydawnictwo Edukacyjne, Warszawa.

Kabata-Pendias A. \& Pendias H., 1999. Biogeochemistry of trace elements (in Polish). Wydawnictwo Naukowe PWN, Warszawa.

KARCZEWSKA A., 2002. Heavy metals in soils polluted with emissions from copper works (in Polish). Zeszyty Naukowe Akademii Rolniczej, Wrocław.

KarczewsKa A. \& Kabata C., 2008. Methodology of soil and plants laboratory analyses, $4^{\text {th }}$ edition (in Polish). Wrocław.

LeECE S.A. \& PAVlowsky R.T., 1997. Storage of mining related zinc in floodplain sediments, Blue River, Wisconsin. Physical Geography 18: 424 - 439.

LewANDOWSKi A. \& PrzeWŁócKi J., 1995. Engineering aspects of pollution in view of case studies carried out in Poland. In: W. Salomons, U. Förstner \& P. Mader (eds.), Heavy metals, problems and solutions. Springer, Berlin.

Lopes-Sanchez J.F., Sahuquilo A., Rauret G., Lachica M., Gomez A., Ure A.M., Muntau H., \& Quevauviller PH., 2002. Extraction procedures for soil analysis. In: $\mathrm{Ph}$. Quevauviller (ed.), Methodologies for soil and sediment fractionation studies. The Royal Society of Chemistry, Brussel.
MiLLER J.R., 1997. The role of fluvial geomorphic processes in the dispersal of heavy metals from mine sites. Journal of Geochemical Exploration 58: 101-118.

Minister of the Environment Regulation of 9 September 2002 on soil and earth quality standards. Dziennik Ustaw 02. 165.1359).

Owens P.N., Walling D.E. \& LeEKS G.J.L., 1999. Deposition and storage of fine-grained sediment within the main channel system of the river Tweed, Scotland. Earth Surface Processes and Landforms 24: 1061-1076. DOI: 10.1002/ (SICI)1096-9837(199911)24:12

Peijnenburg W., Zablotskaja M. \& Vijver M.G., 2007. Monitoring metals in terrestrial environments within a bioavailability framework and focus on soil extraction. Ecotox. Environmental Safety 67: 163-179.

PN-ISO 11466, 2002. Soil quality. Extraction of trace elements soluble in aqua regia (in Polish).

Quevauviller PH., 2002. SM\&T Activities in Support of standardization of operationally-defined extraction procedures for soil and sediment analysis. In: Ph. Quevauviller (ed.), Methodologies for soil and sediment fractionation studies. The Royal Society of Chemistry, Brussel.

Schroeder T., J., Hiemstra T., Vink J.,P.M. \& Van der Zee S.E.A.T.M., 2005. Modeling of the solid-solution partitioning of heavy metals and arsenic in embanked flood plain soils of the Rivers Rhine and Meuse. Environmental Science and Technology 39: 7176-7184. DOI: 10.1021/ es048154s

Schipper A. M., Wijnhoven S. Leuven R.S.E.W., Ragas A.M.J. \& HeNDRIKS A.J., 2008. Spatial distribution and internal concentrations of terrestrial arthropods in a moderately contaminated lowland floodplain along the Rhine River. Environmental Pollution 151: 17-26. DOI: 10.1016/j.envpol.2007.03.007

TAYLOR M., 1996. The variability of heavy metals in floodplain sediments: a case study from Mid - Wales. Catena 28: 71-87. DOI: 10.1016/S0341-8162(96)00026-4

Tessier A., Campbell P.G. \& Bisson M., 1979. Sequential extraction procedure for the speciation of particulate trace metals. Analytical Chemistry 51: 844-851.

WALLING D.E. \& OWENS P.N., 2003 The role of overbank floodplain sedimentation in catchment contaminant budgets. Hydrobiologia 494: 83-91. DOI: 10.1023/A: 1025489526364

Vandecasteele B., Samyn J., Quataert P., Muys B. \& Tack F.M.G., 2004. Earthworm biomass as additional information for risk assessment of heavy metal biomagnification: a case study for dredged sediment-derived soils and polluted floodplain soils. Environmental Pollution 129: 363-375. DOI: 10.1016/j.envpol.2003.12.007

Van Gestel C.A.M., 2008. Physico-chemical and biological parameters determine metal bioavaiability in soils. Science of the Total Environment 406: 385-395. DOI: 10.1016/j.scitotenv.2008.05.050

Zhao Y., Marriott S., Rogers J. \& IwUgo K., 1999. A preliminary study of heavy metal distribution on the floodplain of the River Severn, UK, by a single flood event. Science of the Total Environment 243/244: 219-231. DOI: 10.1016/S0048-9697(99)00386-1 